\title{
EXPLORING DEATH AND GRIEF: \\ ZEN IN ZADIE SMITH'S \\ THE AUTOGRAPH MAN
}

Brno Studies in English

Volume 46, No. 2, 2020

ISSN 0524-6881 | e-ISSN 1805-0867

https://doi.org/10.5817/BSE2020-2-16

\section{BEATRIZ PÉREZ ZAPATA}

\begin{abstract}
This article analyses how Zadie Smith's The Autograph Man (2002) portrays the individual trauma of loss of Alex-Li Tandem, a Chinese-Jewish Englishman, who experiences prolonged grief after the death of his father. More specifically, this article provides an in-depth analysis of grief and argues that it is through Zen Buddhism that Alex eventually accepts death in general and is finally able to participate in Kaddish, a Jewish ritual to remember the deceased. Moving away from previous analysis of the novel's postsecularism and trauma in general, this article focuses on the portrayal of mourning, the interrogation of contemporary approaches to death and bereavement, and the role different spiritual traditions play in Alex's process of working through.
\end{abstract}

Key words

Zadie Smith; mourning; grief; prolonged grief; Zen

\section{Introduction}

Grief has been, and still is, a recurrent topic in literature that portrays a complex personal experience that is difficult to overcome and share. In a society which, as Julia Bandini (2015: 349) argues, is "death-denying" and where traditional tools for coping have been lost in favour of medicalization, literature may come to the fore as a helpful shared experience of loss. In his study of the representation of death and grief in literature, John Skelton (2003: 213) concluded that "one of the central tasks of literature is to impose a structure on life and death, giving meaning to both". Indeed, the success of Joan Didion's The Year of Magical Thinking (2005), Joyce Carol Oates's A Widow's Story (2011), Helen Macdonald's $H$ is for Hawk (2014), Max Porter's Grief is the Thing with Feathers (2015), or Han Kang's The White Book (2017) attests to the importance of grief narratives in contemporary literature, especially in the form of memoirs and autofiction, and proves that both writers and readers seek meaning out the experience of loss.

The Autograph Man narrates the life of Alex-Li Tandem, born in London to Sarah, a Jewish mother, who considers herself to be a Buddhist, and Li-Jin, a Chinese man, who converted to Judaism when he married Sarah. The structure of the novel reflects Alex's hybridity: the "Prologue" describes the days leading to Li-jin's death, caused by a brain tumour at the age of thirty-six and when Alex is twelve-years old; Book One, "Mountjoy: The Kabbalah of Alex-Li Tandem", flashes forward to Alex aged twenty-seven, turned into an autograph man who refuses to participate in Kaddish, a Jewish mourning ritual to remember his 
father's death; and Book Two, "Roebling Heights: The Zen of Alex-Li Tandem", narrates Alex's journey to New York for the Autographicana convention and his search for classical film actress Kitty Alexander, with whom he has been obsessed for a long time.

As an adult, Alex is described as "emotionally undeveloped", "in denial of death", "suspicious of enlightenment" and highly dependent on any type of entertainment (63). He has not accepted the early death of Li-Jin and is continually acting out, that is, unconsciously bringing to the surface his bereavement. The narrative revolves around his avoidance of Kaddish, a ritual described in the novel as "a conversation between Jew and God, son and absent father [...] It's one-onone, though the community is still essential" (404). Several analyses of the novel pay attention to the role of Kaddish in Alex's overcoming of grief, especially as he moves from individualism and private prayers to collective mourning. However, most studies overlook the fact that, before he recites Kaddish, first privately and then collectively, he must accept death as a matter-of-fact phenomenon. Some studies of the novel refer to grief but, so far, there has been no in-depth exploration of it. Urszula Terentowicz-Fotyga (2008: 67) considers Alex's movements towards the imaginary and how "Book Two" confronts him with reality. Philip Tew (2013: 85) studies the most individual aspect of Alex's trauma and argues that "his unresolved grief prevails, negating any [...] sense of order or balance" (80-1). Jorge Berástegui-Wood (2014) explores Alex's identity in connection to a generational trauma and the inherited historical trauma of the Holocaust, which is a collective loss he must also confront. Andrew Furman (2005), Sigrun Meinig (2007), and Magdalena Mączyńska (2009) analyses the Jewishness of the novel, the latter including it within postsecular literature. More recently, Songyun Zheng (2018) has analyses this postsecular view in order to emphasise "the role religion plays in identity formation and narrative construction" (para. 2). Dismissing the mocking tone towards Buddhism that both Maczyńska and Meinig suspected, she argues that Zen helps Alex to configure his multicultural context and that he ultimately shows "spiritual improvement and [...] sophisticated understanding of religious significance" (para. 15). Zen is indeed an undeniable help towards Alex's working through but, although she occasionally refers to Alex's fear of death, Zheng does not connect it with grief.

This article aims to provide a detailed account of the representation of grief in The Autograph Man and specifically focuses on how Zen Buddhism facilitates Alex's process of mourning and acceptance of death, which ultimately allows him to participate in Kaddish. Presenting a close reading of the novel, this paper will show how The Autograph Man proves to be a valuable narrative that exposes the problematics of grief and that appeals to the universality of loss. For that purpose, this article relies on contemporary studies on bereavement and Zen perspectives on death. This study will ultimately lay bare Alex's conflicted journey towards the acceptance of transience and the contradictions in his enlightened understanding as well as contribute to the analysis of grief in literature in general and the study of trauma in The Autograph Man in particular. 


\section{Perspectives on dying and grieving}

Zadie Smith has addressed death repeatedly in her novels, a topic closely connected to her concern about time. In the opening pages of White Teeth (2000), Archie Jones is about to commit suicide, only to be interrupted. Part of the plot of On Beauty (2005) revolves around the death of Carlene Kipps. In NW (2012), Leah Hanwell bases her choice of a degree in philosophy because it teaches you how to die. In Swing Time (2016), the narrator will have to deal with the death of her mother at the end of the novel. But The Autograph Man is the novel that most directly confronts the questions of ageing, death, and loss. Generally perceived to be a lesser novel among Smith's oeuvre and published after perpetuated rumours about her having writer's block, James Wood (2002) deemed the novel to be full of "cartoonishness and excess", of "irrelevant intensities". However The Autograph Man is a novel that should be judged more seriously both narratively and in light of the contemporary discourses on fame, ageing, and dying. Moreover, among the excess, the contradictions, and detours of the plot, the novel, as Skelton argued, tries to provide some meaning to both life and death.

In the first few pages of The Autograph Man, Alex's father, Li-Jin, laments the little time he has left after he is diagnosed with a terminal brain tumour. Li-Jin does not tell his family that he is dying. Even if he cannot verbalise it at times, Li-Jin acknowledges that "he is going to die and it is not going to make any sense but it is still going to happen" (35). If Alex will develop an aversion to the idea of sickness, ageing, and death, Li-Jin seems to accept the inevitability of death in a more serene manner. However, as will be shown, his silence is perpetuated in Alex. As a doctor himself, he faces the fact that there is no treatment possible and that "in the wrestling match between possibly and probably [...] the probably wins nine times out of ten" (35). This allusion to the wrestling match may function to warn readers about Li-Jin's imminent death in the Royal Albert Hall, where he takes Alex and his friends to see a wrestling match and where he will finally collapse, alone. The novel thus establishes a parallelism between Li-Jin's struggle and the event of the wrestling match, contrasting his quiet death against the spectacle of fame. But in the novel, Li-Jin's death takes centre stage and will be the defining event in Alex's life and narrative.

Through Li-Jin's focalization, the novel presents a direct confrontation with death, bringing to the forefront the idea of transience but never losing sight of its physicality, both through the pain he endures and through the embodiment of grief that the Royal Albert Hall presents. The building invites a griefladen reading by evoking Queen Victoria's mourning of Prince Albert, which continues forty years after his death in a rather ritualistic manner. The narrator explains that Victoria's intense and long experience of grief, which would still be regarded as love in the nineteenth century, would now be classified as a syndrome because syndromes "had simpler names back then. It was a simpler time" (18). Nowadays, the narrator argues, this form of grieving would probably have a name such as "Excessive Grief Syndrome (EGF)" (18). Indeed, this diagnosis recalls DMS-5's Prolonged Grief (PG), Complicated Grief (CG) and Persistent Complex Bereavement Disorder (PCBD), which are used to classify different 
experiences of abnormal grief, that is, grieving processes that go on for an unusually long period of time. However, the tone in this passage, which is cautionary and even derisive at times, criticises the medicalization of grief, which rather than being seen as a common human emotion has come to be regarded as something to be quickly worked through. The narrator seems to imply that, although psychoanalysis and psychiatry have named and classified the symptoms of grief as pathologies and provided some methods of healing, they have, in fact, complicated some aspects of a common human experience. In fact, Julia Bandini (2015: 351) warns that the medicalization of grief could ultimately "erase human difference and individuality in the grieving process". The Autograph Man redresses this issue by presenting a very particular case of grief, one that is not only the result of losing a parent too early but also one that tries to navigate different traditions and cultures.

Queen Victoria's grief proleptically announces Alex's inability to accept the death of his father. In addition, from the beginning, The Autograph Man deals critically with the way in which mourning has become an individual issue. Mark Edwards (1997: 444; 450) argued that "modern life" propels "a type of disenfranchised grief", that which "is not acknowledged openly, publicly mourned, or socially supported" and "felt as a sense of meaninglessness". Against this modern experience, which Alex mirrors later on, the Royal Albert Hall is conceived as a site of memory that makes others participant in the collective mourning of Prince Albert, "fe[eling] things in unison" (19) and thus being more constructive when overcoming grief. The novel highlights the importance of having the support of the communities to which one belongs, which has become unusual in increasingly atomized societies. Furthermore, this emphasis on collective mourning forecasts the importance that this will have in Alex's process of working through as the narrative moves toward his participation in Kaddish.

The end of the "Prologue" is marked by Li-Jin's death. He dies alone, surrounded by a crowd, while Alex is backstage getting the autographed picture of a famous wrestler. This devastating scene also contrasts Li-Jin's anonymous death with the death and mourning of public figures. However, unlike Prince Albert, the mourning of Li-Jin is a more complex affair, especially so when the next section opens when Alex is twenty-seven years old. This flash-forward, and the ellipsis it entails, prevents the reader from witnessing and experiencing any type of mourning, thus carrying grief across time. Moreover, this abrupt chronological break suggests that mourning has not occurred and that the silence that Li-jin granted to his illness and impending death has continued in Alex's life. Alex has become an immature, lost adult who has not found meaning for life or death. The novel will respectively use the frames of Judaism and Zen Buddhism in "Book One" and "Book Two" - although both are interlinked throughout the novel - to illustrate how Alex still struggles with bereavement and his journey towards the acceptance of death in general and his father's in particular. 


\section{Acting out: Death, history, and fame}

Several critics agree that, as an adult, Alex is a traumatised man who is unable to work through his father's death. Berástegui-Wood (2014: 21) explains that Alex's problem is that he is unable to accept pain and aptly points that his pain is more "existential" in that he cannot deal with ageing and dying, what Berástegui-Wood calls "the traumatic side of life". Similarly, Tew (2013: 57) argues that Alex displays "a radical avoidance of pain and suffering" that impedes any reconciliation or working through. Andrew Furman (2005:12) contends that Alex's "unresolved grief $[. .$.$] precludes him from achieving meaningful relationships with others,$ including his mother, Sarah, and Esther Jacobs, his girlfriend". Although these scholars do not directly address grief, they have all, in fact, approached the description of what abnormal grief entails. Lundorff et al (2017: 138-9) explain that those affected by Prolonged Grief Disorder present symptoms such as "a pervasive yearning for the deceased or persistent preoccupation with the deceased accompanied by intense emotional pain [...] difficulties in engaging in social or enjoyable activities, a reduced ability to experience positive mood, and difficulties accepting the death of the loved one". Alex will display most of these symptoms throughout the novel and his pain will be shown to be mostly the result of acting out of his father's death.

Alex's avoidance of pain is reflected at the beginning of "Book One: The Kabbalah of Alex-Li Tandem", which starts after he crashes his car against a bus stop while hallucinating on drugs. Other characters, such as his friend Adam and even Marvin, the milkman, start to show their concern for his psychological well-being. Alex admits to being depressed (56) and complains that "everything felt heavy" (62). Although he acknowledges that he has some problems, he believes he can solve them on his own and rejects therapy (99). To fight this sensation of psychosomatic heaviness, he takes some tea prescribed by Dr Huang, the same doctor his father visited. But the remedies he takes do not seem to work well enough because, rather than confronting what is causing the pain that he feels, Alex only accepts patches that provide a quick but unconvincing fix. According to Amber D. Carpenter (2012: 38), nowadays, "pain is always a mistake, a failure of good psycho-biological functioning to be remedied through technical terms". Carpenter (2012: 43) considers Buddhist perspectives, which see pain "inevitable". This is a lesson that Alex will learn in the course of the novel.

The visits to Dr Huang and other Western doctors reveal a hypochondriac behaviour that stems from his father's sudden death. He takes medicines to "wardoff $[\ldots]$ his genetic time bomb, his cancer gene $[\ldots]$ to stave off the inevitable" (147). When he becomes aware of the "memory loss" that his acid trip has induced he believes he has "a rare blood disease and (in all probability) the early stages of lymphatic cancer" (158). His obsession with the development of cancer is his way of acting out his sudden loss and the symptoms of "confusion, depression, forgetfulness, anger, weepiness, violence, feelings of worthlessness" (147) fit those of a traumatised person, but he confuses them with the secondary effects of the medicine he is taking to avoid dying like his father. Moreover, his recurrent 
visits to Dr Huang throughout his adulthood also attest to his pain, since they evidence an unresolved attachment to his father's death.

However, there is one instance in which Alex seems to confront pain and death straight on: he goes to South London once a week to visit Duchamp, a colleague who is dying. He claims that he enjoys South London because of his anonymity there, which he compares to "being dead" and so "every Thursday morning, Alex died. Every Thursday morning Duchamp was the only mourner" (167; italics and underline in original). Once there, he observes Duchamp, who "didn't look scared, though [...] It was only Alex who was feeling a terror grip him. A selfish terror. How few Thursdays Duchamp has left to him! How many do I have? (168; italics and underline in original). Philip Tew (2010: 83) contends that "Alex fears Duchamp's physical and mental degeneration, which in contrast to his father's secret, private demise, allows anticipation of Duchamp's death. Through Duchamp Alex relives more dramatically the origins of his own fear and self-obsession, the trauma of paternal loss and absence". Yet, this is another example of Alex's attempts to masquerade his acting out. At this stage, Alex is still in denial and, in his mind, the event of death is reversed so as to prevent him from adopting the position of the mourner.

In addition to his individual trauma of loss, Alex also has to deal with the inherited collective and historical trauma of the Holocaust. Furman (2005: 12; 14) argues that Alex is "beset by traumas particular to his experience as a Jew at a specific point in history, and one who ultimately relies upon his Judaic legacy, both inherited and adopted, to grapple with these traumas". However, the example that he chooses to support his argument, the moment when Alex's mother gives him a box with "trinkets and photographs" of the Hoffman family, leads Alex, not to remember the Jewish genocide, but rather to face the "wear[y]" and "tiring" realization that all of them are dead (92-3). Although there is some latent transgenerational trauma related to the Jewish genocide, here Alex pays special attention to individual deaths. This may infer that Alex, focused only on his own pain, is unable to grasp collective suffering. Furthermore, this realisation could be read in parallel to his refusal to participate in Kaddish, a collective ritual that would involve those closest in his Jewish community.

One of the ways in which Alex avoids confronting his trauma is through his immersion in the world of fame and celebrities. Two of the female characters in the novel suggest that Alex's involvement in the world of celebrities and collecting may be indeed a consequence of loss: Honey tells him that fame "i[s] for amputee people, [for] people who're missing something vital" (255); the first time Kitty meets Alex she can tell that "there is lack somewhere" (287). Tew (2010: 85) thus explains that Alex's trade of autographed photographs is "a failed attempt to transcend his father's demise", given that fame, in a way, "cheats death" (182). On her part, Terentowicz-Fotyga (2008) reads the "Real" in the novel in light of Baudrillard and Benjamin, an argument which is taken up by Berástegui-Wood (2012) in a more Lacanian turn, in which Alex finally incorporates the loss of his father into his psyche. In fact, Smith (2013: n. p.) recalls Lacan's definition of trauma "as "a missed encounter with the real" and what acting out entails, namely that "we mechanically repeat the trauma to obscure and control the real- 
ity of the trauma, but in doing so reproduce, obliquely, some element of trauma". Alex feels rage as he reflects on the fact that famous people "cheat Death" since their images transcend time and are still visible to the world and he eventually confesses that collecting autographs is "what is between me and my grave" (2034). Even when he desperately tries to escape his grief, he finds himself confronted with the very idea of death. Alex also affirms that he seeks the soothing qualities of entertainment because "the point was ease. Always ease. Even if it had to be the kind of ease that makes things more difficult" (296). He eventually realizes that his evasion is at times rather destructive and that suffering or, as Mark Siderits (2007: 20) calls it, "dis-ease" is intrinsic to life.

\section{Grief transcended: Accepting death}

Alex's relationship to death is complex, and so is the novel's intricate use of Judaism and Zen Buddhism to ease this relationship. Neither Judaism nor Zen Buddhism regard death as inherently traumatic. Jack Riemer (1995: 21) explains that "in Jewish thought, death is not only the inevitable end of life, it is also a constant companion and possibility within life", a viewpoint which, he goes on to argue, is not "morbid", but rather makes people more aware of life itself. Similarly, Buddhist theories explain that, once one has acknowledged "the certainty of death and the uncertainty of its time", the death of others stops meaning "discomfiture" to become an "awesome and tragic conclusion to the transience that lies at the heart of all life" (Batchelor, 1998: 33). It is no wonder that, according to Lundorff et al. (2017: 144), Prolonged Grief Syndrome is "higher in Western studies than in Eastern studies". Thus, Smith presents two cosmovisions that might clash with the contemporary avoidance of the topic of death and pain, and somehow depart from psychoanalytical accounts restricted to the concepts of mourning and melancholia. For the moment, Alex rejects the possibility of mourning. His memories and his relationship with the past are sealed off by temporary remedies and his pain will not be alleviated until he opens up to the possibility of mourning and accepts that life is transitory and death, inevitable.

Beyond easily assumed ideas and the Western commodification of Zen and Buddhism (see, for example, Éric Rommeluère, 2015 and Ronald Purser, 2019), the inclusion of Zen in the novel should be regarded as a tool that can help us deal with pain, understand our place in the world, and bolster healing in a manner similar to psychoanalytical methods of therapy. For Erich Fromm, D.T. Suzuki, and Richard de Martino (2013: 77) both psychoanalysis and Zen "deal with the nature of man and with a practice leading to his transformation" and thus have the common aim of tackling the crises of existence. Fromm, Suzuki, and de Martino (2013: 50-51; 65) further argue that psychoanalysis and Zen share the aim of making "conscious the unconscious", while remarking that, despite popular belief, the idea of enlightenment has to do more with having "one's mind free and unobstructed" than with mystic awakenings since its ultimate purpose is "to get in touch with reality". The Zen path established for Alex in the novel leads towards this confrontation with reality. He must determinedly face his father's 
death, and thus his own fear of death, so that he can live in the real world without falling back into the escapism that the world of fame and celebrities provide. But in his current state of mind, Alex cannot proceed with such confrontation.

As the first book in The Autograph Man moves towards its end, Zen is presented in a more philosophical manner. Boot, a girl with whom Alex has been having an affair, finds him with a nosebleed and possibly a broken nose after he tried to sell an allegedly fake autograph to a colleague. Alex refuses to go to a Western doctor and goes to see Dr Huang. In a flashback, readers are informed that Sarah had brought Alex here shortly after Li-jin's death to ask him "why [...] he had poisoned her husband" (188). Unable to understand her husband's death, Sarah comes to Dr Huang's office looking for an answer, but the only one she gets is a Zen koan (paradoxical riddle without a logical solution) called "Real Prosperity". In this Zen story, Sengai, a Japanese monk, writer, and painter, explained that the real prosperity for a family is that all its members die in the expected order - "father dies, son dies, grandson dies" - because this is "the natural course of life" (89). Although this story intends to show that Li-Jin's death should not be the cause of prolonged grief, it is no consolation at the time, for Alex is left confused and Sarah cries even more.

In the realm of psychoanalysis, Freud reached a similar conclusion. In her study of grief in Freud and Barthes, Kathleen Woodward (1990: 93; 96-97) describes the common experience of "anxiety as well as grief $[. .$.$] in mourning"$ and advocated a search for a mid-point between mourning and melancholia that takes into account affective states. She also recounts how Freud changed his views on mourning and melancholia when the "natural course of life" was altered in his own case. Woodward quotes from The Interpretation of Dreams, in which Freud claimed that losing a father "is the most important event, the most poignant loss, in a man's life". His conviction changed after the death of his fouryear-old grandson, which deprived his life of meaning and precipitated his acute grief. He therefore proposed a revision of mourning in relation to grief and pain, a project he could not finally carry out but which Eastern philosophies had already addressed.

The second book, in The Autograph Man "Roebling Heights: The Zen of AlexLi Tandem", opens with two epigraphs: the first one from Sunset Boulevard (Wilder 1950), the second from the book Zen Flesh, Zen Bones (Reps and Senzaki 1971: 223), which explains that "The bull is the eternal principle of life, truth in action. The ten bulls represent sequent steps in the realization of one's true nature". In their book, Reps and Senzaki (135) argue that to be enlightened is to be conscious, a sudden process that brings to the fore the self's "true nature" as existing in time and always temporal. The Zen concept of true nature relates to nothingness and freedom and proposes that exploration of the self can liberate us from attachment and, ultimately, suffering. Once we realize "the nature of our own being", Suzuki (1996: 4) argues, we will stop harbouring "pessimistic doubts" and accept the facts and changes of life contentedly. If Alex's true nature is to emerge somehow, his trip to the US and his search for Kitty represent his first step into action, his first attempt to abandon the imaginary and search for the reality of time and transience. But, as the title of this second book suggests, Alex's take on 
Zen Buddhism will be a particular one, moving in between the superficial and sudden awakenings.

The second part of the novel includes not only the teachings from The Ten Bulls but also koans that tackle death and grief more directly. In his drug-induced delusion, Alex purchases two plane tickets to go to the Autographicana convention in New York to try and meet Kitty Alexander. In the plane, he listens to "a sub-Zen relaxation tape that consists of an LA therapist whispering koans over the sound of the sea" (219). Under this subtle mocking of the West's take on Zen, a story of grief emerges: "a distraught mother begged Buddha to heal the dead child in her arms. He did not perform a miracle. He said 'Bring me a mustard seed from a house where no one-"' (219). The end of this koan is elided because Alex is interrupted by a flight attendant, which once again allows the novel to play with ellipsis. Even if the interruption is involuntary, it parallels Alex's deliberate ignorance about death. Moreover, I would argue that the novel invites readers to search for the end of the koan. Thus, we learn that this koan continues: "had ever died. She returned from her search without the seed, but with the knowledge that death is universal" (as cited in Fields, 1992: 9). Death should be accepted even when it feels unnatural. Formally, the second book works towards providing Alex with the truth that he, at this time, cannot know or refuses to know.

After that brief interruption, Alex goes back to the tape, where "the Zen lady says, 'Knowledge is the reward of action, because it is by doing things that we are transformed. Executing a symbolic gesture, truly living through a role, this is when we come to realize the truth inherent in the role. When we suffer its consequences, we fathom and exhaust its contents"' (221). Immediately after, Alex changes the channel to watch Casablanca. Sigrun Meinig (2007: 74) reads this passage as yet another example of the importance of gestures and ritual in Judaism in general and the novel in particular and connects it with Bhabha's notes on humour. I agree to Meinig's contention that Alex's reaction, or rather inaction, is an ironic take. Nevertheless, this passage, which can be traced to Heinrich Zimmer's exploration of Buddhism in his work Philosophies of India (1952: 544), is, in fact, a call for "a bold and advertent living of life". In a novel in which the protagonist exploits inaction and in which "taking action" is even used as a metaphor for suicide (180), the allusion to gestures and the roles rather suggest a letting go of one's ego. But Alex clings to old habits and to his object of loss.

Kitty and other characters Alex encounters in New York will nevertheless make him confront Zen lessons on transience and non-attachment. Such is the case of Honey Richardson, a woman with whom he had traded autographs before. She describes herself as a Buddhist "in [her] own way" and lectures Alex on the impermanence of pleasure using coffee as an example. More importantly, she claims that she wants to scream "Mu" to everybody. She explains that "mu" is "a Buddhist word" and that "it's how [she] let[s] go of things" (243). His first encounter with Honey ends when she tells him that "shit happens. That's Buddhism too" (244), an apt if brazen description of what Buddhism entails. He then goes to the Autographicana convention. Upon seeing "at least a thousand Autograph Men [...] Alex's first instinct was to turn and run, screaming MUUUUUUUUU through the streets of the city" (245; italics in original). He has internalized 
Honey's teachings rather quickly; however, it is not a lesson taught to others but to himself alone. Alex is forced to admit that there is more to him and his life and death than fame and being an autograph man. Furthermore, he is forced to admit that his trade is indeed tied to death.

The Autographicana offers a varied environment with paraphernalia from film, literature, and sport celebrities, together with the two bombers of Hiroshima and "lot[s] of Nazi stuff" (245-6). Those objects that remind him of the Holocaust and the Second World War further trigger off his latent anxiety built up from an inherited historical trauma and denial of death. Before long, Alex "could feel himself growing hysterical. And they just kept on collecting! As if the world could be saved this way! As if impermanence were not the golden rule! And can I get Death's autograph too? Have you got a plastic sheath for that, Mr. Autograph Man?" (247). Alex sets himself apart from an alienating world. This sudden realization, which follows Zen's learning patterns, causes an estrangement that allows him to realize that, as an autograph man, he has inadvertently been trading with death all along.

Andrew Furman (2005: 13) argues that Alex "comes to realize in New York [...] the futility of such efforts to stave off change and, ultimately, death". His trip to New York helps to materialize a city he has only known through films (226) and provides him with a chance to confront reality instead of inhabiting a mediated, imagined world. This growth also involves his relationship with Kitty. Alex eventually goes to her house and before she opens the door, Alex ponders on a photograph showing a young Kitty: "That is the face. The one he loves. Why subject it to Buddha's rules of impermanence?" (272). If some pages before he had claimed that everything was subjected to the rules of impermanence, here Alex contradicts himself to make an exception out of Kitty. His encounter with Kitty meets all of his expectations and thus he "feel[s] very calm" and "Zen" (276). This statement, together with a reference to Zen in "Martha, Martha" (Smith, 2003), led Zheng (2018: para. 10) to conclude that "in Smith's writing being Zen denotes calm, beauty, and a peaceful mood with no fear of death". However, this is a deliberate misconstruction of it, for Alex only relies on Zen when there is a positive outcome, which contradicts Zen's urge to accept the fact that one does not often get what one wants or anticipates, but rather gets what one does not want; and this includes the fact that Kitty is also going to die.

Much of Alex's acceptance of reality is prompted by Kitty's deconstruction of his belief that she will "live for[ever]" on film and will continue to look young despite the passing of time. Kitty tells him that he is "being ridiculous" and speaks openly of her fear of death and the fact that she "will go alone" (308-9) because she is "no one at all" (287). In New York, Alex develops a close relationship with Kitty, who he feels the need to protect against all odds. After a short time, he spends the night at her house, "like a sentry, one eye out for death" because "of all the possible deaths that stalk everyone every day, at this moment hers feels the most unbearable" (309). It is Kitty, rather than Duchamp as Tew (2010: 83) argued, the one who allows Alex to anticipate death more clearly. He will have to let go of this object of love, which thus becomes an anticipated loss. Through Kitty, Alex realizes the scope and meaning of death and she becomes the charac- 
ter that allows him to confront the real and face the memory and remembrance of his father's death.

The following day, Alex is on a park bench with a copy of the mourners' Kaddish in his hands: "there was no good reason to be doing this unless one accepted that the very lack of reason made it worth doing - a perfect Jewish formulation. But that wasn't it. She had said something" (313). That something is that "you never know, until it happens, what you will owe the dead" (313-4). Alex repeats this last sentence in his mind and continues to read the prayer aloud, as a rehearsal for the collective mourning that will take place back in London. This moment marks the beginning of his process of mourning, which will continue once he is back in London.

Alex returns to London with Kitty, slightly changed, more aware, but still determined to make some money for Kitty and himself by selling her autographs, thus giving her a chance to finally escape New York and Max, the obsessive president of her fan club, who has scammed her. Kitty and Alex's plan is altered when they hear on television that Kitty has died: Max has supposedly reported her dead. And her alleged death is not special: the television "spend[s] barely a minute on this death, 152,460th of the day" (352). Significantly, the news is accompanied in the novel by the drawing of three blank television screens with different captions about her life. It is no coincidence that Kitty's "death" occurs in chapter eight, "Both Bull and Self Transcended". The illustration of nothingness with an empty circle in the Zen book is here replaced by the empty television screen. Mark Edwards (1997: 448) explains that "experiencing the reality of absence and emptiness is also fundamental to the practice of Zen". Therefore, fame and life are here depicted as the "MU" that Honey mentioned, a void from which change can follow because nothing in life is permanent.

This chapter offers yet another transformative experience when Alex goes to see Duchamp, who is by now in hospital, an environment which Alex loathes, especially when he encounters young people and babies, some of whom are terminally ill. Seeing this throws him into another hysterical rant similar to the one he had in the Autographicana convention and he asks himself "What is going on here?" (370; italics in original). In fact, it is a lesson. Alex learns what he could not hear in the second koan on the plane to New York. This is direct, unmediated exposure to the real fact that death is universal and that even deaths that do not follow a natural order have to be accepted. Rather than being a case of allowing Alex to anticipate a certain death, seeing Duchamp in hospital allows Alex to accept death as a universal fact. However, he still finds it difficult. When Rabbi Burston, who will officiate at the Kaddish, tells him that we should all accept God's will, however twisted, Alex rejects it, arguing that all the suffering he has previously witnessed at the hospital is simply "obscene" (407). As was mentioned earlier on in this article, neither Zen nor Judaism regard death as traumatic and Alex will have to accommodate all of their views to properly mourn his father and transcend his grief. 


\section{Life and death reconciled}

Chapter eight in the The Autograph Man, the one that presents death more directly, closes with a memory of laughter: Alex's friend Adam goes to Alex's home a year after Li-Jin's death, "amused about something". Neither Sarah nor Alex "had dared smile [...] for a year, not since it happened". When they are still unable to name Li-Jin's death, Adam brings a smile. Alex can remember "the radiance of the laugh", "the repeated dawn of the smile", and how Adam "knew even then that one person's capacity for joy can pinch those people who can't manage it" (373-374). This memory of grief and joy together shows the importance that his community of friends has had over the years and the fact that joy and pain, life and death, coexist in his world.

The novel works up towards Kaddish by repeatedly making Alex face the idea of death in a short span of time. He now realises that "the dead walk", because all the people surrounding him will eventually die. Once in his house, he points out that "he was looking at them now. On the walls in black and white, but also in this bed, in full Technicolor. A child knows this, and is told to get over it. [...] But it was still really messing with Alex" (392). If Alex has ever addressed grief at all, he has done so as mediated by popular discourses, which gives him enough distance with the object of mourning so as not to feel his grief. Moreover, he wants to deal with death like a "grown man" (italics in original) but cannot do so. The novel does not disclose who tells Alex to get over his father's death, but it does suggest that the way to move forward from bereavement is to suppress any negative feelings associated with bereavement, which is especially pernicious in discourses of masculinity. But a change occurs:

$[\mathrm{H}] \mathrm{e}$ took it (death) cinematically, or televisually - if he took it at all. But here it came - he tried to grab the top of the door-frame to keep himself up - here was the death-punch, the infinity-slap, and it was mighty. He wheeled away from the spot, clutching in his hand something he had accidentally ripped from the wall, his mouth was open like someone had kicked a hole in his face. But he made no noise. He didn't want to wake the dead. He had control, still. He found some spot where he could not be heard, hot and dry and full of towels, and said his Kaddish without gesture or formality - just a wet song into his hands. (392)

Here, Alex finally allows himself to feel his father's death and the narrative parallels his working through with the words Li-Jin used to describe his own death - "the death punch, the infinity slap"- and his actions like holding whatever is at hand and weeping with his mouth stuffed so as not to be heard. Repeating, even if unknowingly, his father's death and experiencing the transformative pain of grief is not a form of acting out but rather of finally working through, which enables him to say Kaddish individually before re-entering his community.

Berástegui-Wood (2014: 26-27) analyses the above passage as Alex's confrontation with the Lacanian Real and argues that "through his personal kaddish, Alex re-inscribes his father in his evolution as a person" (italics in original) and thus 
moves from denial to acceptance. Given that the second part of the book is built up around Zen, it could be more accurate to see this moment as one of enlightenment in the sense proposed by Fromm, Suzuki, and de Martino (see page 10 of this article). For Zheng (2019), Alex's enlightenment seems to arise from his relationship to Kitty and, while she is a facilitator in his understanding of death, I would argue that it is this final re-enactment of Li-Jin's death that truly awakens Alex's consciousness and allows him to re-incorporate himself to both secular and religious worlds.

Soon after, Alex concludes that "he wanted to be in the world and take what came with it, endings local and universal, full stops, periods, looks of injured disappointment and the everyday war. He liked the everyday war. He was taking that with fries. To go" (410; italics in original). Alex, who now expresses with bravado his acceptance of suffering and death, will nevertheless still recriminate Adam because he had promised him that coming to terms with his father's death and participating in Kaddish would "make him feel better". But it does not. As Alex himself asserts: "it doesn't cure anything. I miss him. I still miss him. All the time. I miss him so much. I don't feel better". Adam's answer speaks for itself: "I said it was going to $b e$ better, not feel better" (411; italics in original). The novel does not offer a cure, for death can only be accepted.

If it had not been noticeable before, here the novel lays bare how Alex's life has been governed by his unspoken loss. Even if he did not share it with his community, from the moment of Li-Jin's death and until this moment, his life has been one of continuous attachment to the absent loved one. If he feels lost and he "lives in the past" it is because he is still very much attached to the absent loved one. As Edwards (1997: 449-450) explains, "To experience grief is to know that one must go on living in the absence of a loved one". Moreover, he adds that "The feeling of inconsolable grief for a person who has died [...] become(s) an essential part of who we are [...] Pain and grief continue, but we come to experience life in a different way, and we embrace that experience instead of hiding from it". Alex is finally talking about his father's death and he is sharing his grief with others. No longer in denial of death, he starts to deal with the "dis-ease" that being alive entails.

The novel ends with Kaddish as an epilogue. The significance of this ending has been often analysed as Alex re-entering his community as an enlightened man. Magdalena Mączyńska (2009: 78) believes that the ritual "promises to liberate the young man from the prolonged inertia of his egocentric angst and reintegrate him into the community of friends he had done his best to alienate with his immature behaviour". Slightly more suspicious, Tew contends that Alex might have changed just momentarily and that his participation is rather "ambiguous" (89-90). On her part, Zheng (14) reads this as yet another example of Alex's approximation to his religions. Meinig (72-73) argues that, even if he remains sceptical, this is a lesson on community and against Alex's "excessive individualism and self-consciousness". At the same time, Meinig argues that the prayer, interrupted by Alex's observations of others' gestures works against the idealization of any tradition and religion. In addition to the communal sense of mourning, his remarks are a direct observation of the community that is present, an assertion of the gestures and the quotidian of life in the process of remembering the dead. 
The reading that this article provides is perhaps closest to Berástegui-Wood's (28) conclusion that it is "only through the acceptance of life's tragic dimensions and through the connection with others [that] Alex Li can live a truly meaningful life". By the end of the novel, Alex has already accepted transience and come to terms with the fact that, although the ritual is not going to significantly change anything, it is a necessary process which brings him close to both his father and his community. The novel truly ends with the Kabbalah of Alex-Li Tandem. Its crown appears to be an empty circle, which is completed in the novel with a fivepound note that Li-Jin gave Alex the day of his death. Far from being void, this circle is full of life. Perhaps it may be a good idea to read all these circles, both the ones from the Sefirot and the Ten Bulls, as an enso, which is a representation of both enlightenment and emptiness (Dogen, 2012; Collins, 2010) and which also stands as a symbol of "true reality" (Schumacher and Woerner, 1989: 102). Most definitely, this ending shows that Alex is able to transform his philosophy of "living in the past and always regret everything" through the spiritual and philosophical explorations that Zen and Judaism, two interconnected paths that release unconscious memories and enable him to make sense of his past, present, and future.

\section{Conclusion}

The Autograph Man is an exploration of contemporary approaches to life and death as well as contemporary, multicultural approaches to spirituality and religion. Smith's novel is also an exercise in memory and remembrance and the complications that follow the repression of painful loss. At the beginning of the novel, Alex is both lost in life and at a loss for words, unable to communicate his suffering and seeking entertainment at all cost. If the novel does not offer the possibility to grieve the death of Li-Jin at the end of the "Prologue" and, indeed, suggests that Alex has not mourned his father, "Book One" and "Book Two" let readers accompany Alex in his process of acceptance and working through.

As this article shows, Alex does not follow a traditional path for overcoming his grief. Nevertheless, the narrative forces him into direct and indirect conversations about death and encounters with the natural and "unnatural" deaths that occur every day. Far from becoming a disheartening picture, the novel proposes the integration of the past into the present - a concern repeated in many of Smith's narratives - and encourages both the protagonist and readers to see death as inherent to life. As I have argued, although both Judaism and Zen are closely intertwined in the novel, it is Zen philosophy that ultimately opens Alex's mind to the reality of death and transience. The use of koans, the references to "Mu", and even Alex's (mis)conception of Zen, provide a reflection on the nothingness of life as a starting point for the development of meaning and meaningful lives. Suspicious as he is of enlightenment, Zen ultimately provides him with the spiritual insight about death and prepares him for Kaddish and collective mourning.

The novel establishes a dialogue between different spiritual and philosophical traditions, which opens up the conversation about ways to cope with death. Nev- 
ertheless, the narrative brings to the surface the silences around bereavement. The use of ellipsis both at the end of the "Prologue" and in the koans inserted in the narrative reinforces the idea that death is something which would be rather not addressed, especially in the West. At a time when efforts to ward off ageing and death abound, The Autograph Man is a reminder of the bare facts about living and dying. Fame does not help anybody "cheat death" and uncritical approaches to entertainment do not help Alex at all. It is when he finds the real within this world, when Kitty materialises as yet another human being subject to the passing of time, that Alex starts to make peace with the idea of death. In the end, there is no grand gesture of transcendence, only the acceptance of "endings local and universal, full stops, periods" (410).

\section{References}

Bandini, Julia (2015) The Medicalization of Bereavement: (Ab)normal Grief in the DSM-5. Death Studies 39, 347-352.

Batchelor, Stephen (1998) Buddhism without Beliefs: A Contemporary Guide to Awakening. London: Bloomsbury.

Berástegui-Wood, Jorge (2014) The Autograph Man, by Zadie Smith: The Long Way to Heal Trauma. The Southeast Asian Journal of English Language Studies 21 (3), 19-30.

Carpenter, Amber D (2012) Metaphysical Suffering, Metaphysics as Therapy. In: Hinnerman, Nate and Matthew Lewis (eds.) On Suffering: An Inter-disciplinary Dialogue on Narrative and the Meaning of Suffering. Oxford: Inter-Disciplinary Press.

Collins, Richard (2010) Honoring the Form: Zen Moves in Charles Johnson's Oxherding Tale. Religion and the Arts 14 (1-2), 59-76.

Dogen, Zenji (2012) Treasury of the True Dharma Eye: Zen Master Dogen's Shobo Genzo. Edited by Kazuaki Tanahashi. Boston: Shambhala.

Edwards, Mark (1997) Being present: experiential connections between Zen Buddhist practices and the grieving process. Disability and Rehabilitation 19 (10), 442-451.

Fields, Rick (1992) How the Swans Came to the Lake: A Narrative History of Buddhism in America. Boston: Shambhala Publications.

Fromm Eric, D.T. Suzuki, and Richard De Martino (2013) Psychoanalysis and Zen Buddhism. New York: Open Road.

Furman, Andrew (2005) The Jewishness of the Contemporary Gentile Writer: Zadie Smith's The Autograph Man. Melus 30 (1), 3-17.

Lundorff Marie, Helle Holmgren, Robert Zachariae, Ingeborg Farver-Vestergaard, and Maja O'Connor (2017) Prevalence of prolonged grief disorder in adult bereavement: A systemic review and meta-analysis. Journal of Affective Disorders 212, 138-149.

Maciejewski Paul K., Andreas Maercker, Paul A. Boelen, and Holly G. Prigerson (2016) 'Prolongued grief disorder' and 'persistent complex bereavement disorder', but not 'complicated grief', are one and the same diagnostic entity: an analysis of the data from the Yale Bereavement Study. World Psychiatry (15), 266-275.

Mączyńska, Magdalena (2009) Toward a Postsecular Literary Criticism: Examining Ritual Gestures in Zadie Smith's 'Autograph Man'. Religion and Literature 41 (3), 73-82.

Meinig, Sigrun (2007) What's more important than a gesture? Jewishness and cultural performativity. In: Stähler, Alex (ed.) Anglophone Jewish Literature. London: Routledge, $65-75$.

Purser, Ronald (2019) McMindfulness: How Mindfulness Became the New Capitalist Spirituality. London: Watkins Media. 
Reps, Paul and Nyogen Senzaki (1971) Zen Flesh, Zen Bones. Harmondsworth: Penguin.

Riemer, Jack (1995) Wrestling with the Angel: Jewish Insights on Death and Mourning. New York: Schocken Books.

Rommeluère, Éric (2015) S'Asseoir Tout Simplement: L'Art de la Méditation Zen. Paris: Seuil.

Schumacher, Stephan and Gert Woerner (eds.) (1989) The Rider Encyclopaedia of Eastern

Philosophy and Religion. London: Rider.

Siderits, Mark (2007) Buddhism as Philosophy: An Introduction. Aldershot: Ashgate.

Skelton, John (2003) Death and Dying in Literature. Advances in Psychiatric Treatment 9, 211-220.

Smith, Zadie (2000) White Teeth. London: Penguin.

Smith, Zadie (2002) The Autograph Man. London: Penguin.

Smith, Zadie (2003) Martha, Martha. In: Smith, Zadie Martha and Hanwell. London: Penguin, 1-24.

Smith, Zadie (2005) On Beauty. London: Penguin.

Smith, Zadie (2012) NW. London: Penguin.

Smith, Zadie (2013) Man vs. Corpse. The New York Review of Books, December 5, 2013.

Smith, Zadie (2016) Swing Time. London: Penguin.

Suzuki, D.T. and William Barret (1996) Zen Buddhism: Selected Writings of D. T. Suzuki. New York: Doubleday.

Terentowicz-Fotyga, Urszula (2008) The Impossible Self and the Poetics of the Urban Hyperreal in Zadie Smith's The Autograph Man. In: Walters, Tracey L. (ed.) Zadie Smith: Critical Essays, 57-72.

Tew, Philip (2010) Zadie Smith. New York: Palgrave Macmillan.

Tew, Philip (2013) Celebrity, Suburban Identity and Transatlantic Epiphanies. In Tew, Philip (ed.) Reading Zadie Smith: The First Decade and Beyond. London: Bloomsbury Academic, 53-68.

Wood, James (2002) Fundamentally Goyish. London Review of Books 24 (19), 17-18.

Woodward, Kathleen. 1990. Freud and Barthes: Theorizing Mourning, Sustaining Grief. Discourse 13 (1), 93-110.

Zheng, Songyun (2018) Postsecular return of religion: Jewish and Zen elements in Zadie Smith's The Autograph Man. Neohelicon 45 (1).

Zimmer, Heinrich (1952) Philosophies of India. London: Routledge.

Beatriz Pérez Zapata is an assistant lecturer in English for Specific Purposes and Education at TecnoCampus (University Pompeu Fabra) and at Valencian International University. She obtained her PhD from the University of Zaragoza. Her research has analysed the work of Zadie Smith through trauma and memory studies. Her interests are Postcolonial literature, Black-British literature, and refugee literature.

Address: Dr. Beatriz Pérez Zapata, TecnoCampus (University Pompeu Fabra), Escuela Superior Politécnica, Parc TecnoCampus Mataró-Maresme, Carrer d'Ernest Lluch, 32, 08302 Mataró, Barcelona, Spain. [aperezz@tecnocampus.cat] 